\title{
Two regimens of sultamicillin in treating uncomplicated gonorrhoea
}

\author{
C FARTHING,* R N THIN,* S SMITH,† AND I PHILLIPS† \\ From the Departments of *Genitourinary Medicine and †Microbiology, St Thomas's Hospital, \\ London SE1 7EH
}

SUMMARY Sultamicillin is a covalent union of ampicillin and the $\beta$ lactamase inhibitor, sulbactam (CP-45,899). Two studies were conducted to assess its efficacy in treating uncomplicated gonorrhoea. In the first study treatment comprised sultamicillin $1.5 \mathrm{~g}$ and probenecid $1 \mathrm{~g} ; 124(89 \cdot 2 \%)$ of 139 patients responded including seven of 11 patients harbouring $\beta$ lactamase (penicillinase) producing strains of Neisseria gonorrhoeae (PPNG). In the second study sultamicillin $2 \cdot 25 \mathrm{~g}$ and probenecid $1 \mathrm{~g}$ were given; $122(93 \cdot 8 \%)$ of 130 patients responded. Only two of seven pharyngeal infections resolved, and if pharyngeal infections are excluded the overall cure rate rose to $95 \cdot 3 \%$. Thirteen of 14 patients infected with PPNG strains were cured by the larger dose. Side effects were mild and transitory. It may be concluded that sultamicillin $2 \cdot 25 \mathrm{~g}$ plus probenecid $1 \mathrm{~g}$ is an effective regimen to treat uncomplicated rectal and genital gonorrhoea and is useful for treating infections with PPNG strains. Most $\beta$ lactamase resistant antimicrobials must be given parenterally; sultamicillin is given by mouth.

\section{Introduction}

Sultamicillin is a covalent union of two antimicrobials, the semisynthetic penicillin, ampicillin, and the $\beta$ lactamase inhibitor, sulbactam $(C P-45,899)$. We conducted two studies to see if a single dose of this new drug would be effective in treating gonorrhoea due to $\beta$ lactamase (penicillinase) producing strains of Neisseria gonorrhoeae (PPNG) and non-PPNG, and to see if it was an acceptable alternative to spectinomycin and the new cephalosporins in treating infection with PPNG strains.

\section{Patients and methods}

We studied all patients with uncomplicated gonorrhoea attending the department of genitourinary medicine at this hospital during the study periods 1 November 1982 to 5 January 1983 and 9 March to 1 June 1983 except those hypersensitive to penicillin, travellers unable to attend for follow up, patients in whom syphilis was suspected, women not using oral contraception or an intrauterine device (IUD), and patients who declined to take a new drug.

Address for reprints: Dr R N Thin, Department of Genitourinary Medicine, St Thomas's Hospital, London SE1 7EH

Accepted for publication 28 May 1984
Presumptive diagnoses were made by microscopical identification of typical Gram negative intracellular diplococci in smears taken from the urethra and, when indicated, from the rectum of men, from the urethra and cervix of all women, and from the rectum of sexual contacts. Specimens from the same sites, and the pharynx when indicated, were also cultured on selective medium ${ }^{1}$ for $N$ gonorrhoeae; cases not confirmed by culture were excluded.

Minimum inhibitory concentrations (MICs) of ampicillin alone and ampicillin and sulbactam in a 1:1 ratio were measured for all but 20 of the isolates in the first trial and all except nine in the second. All organisms with MICs of ampicillin of $0.25 \mathrm{mg} / \mathrm{l}$ or more were assessed for production of $\beta$ lactamase as already described. ${ }^{2}$

All patients were observed while swallowing the appropriate number of $\mathbf{3 7 5} \mathrm{mg}$ sultamicillin tablets and two $500 \mathrm{mg}$ tablets of probenecid. They were then asked to return after 1,7 , and 14 days. At each visit they were examined, and smears for Gram staining and cultures were taken as above. Patients in whom culture positive gonorrhoea was found during the follow up period and who admitted to having had sexual intercourse were excluded.

\section{Results}

In the first trial 168 patients with gonorrhoea were treated with $1.5 \mathrm{~g}$ sultamicillin and $1 \mathrm{~g}$ probenecid; 
TABLE I Patients treated with $1.5 \mathrm{~g}$ or $2.5 \mathrm{~g}$ sultamicillin and $1 \mathrm{~g}$ probenecid in two trials and those excluded from analysis

\begin{tabular}{llllll}
\hline & No treated & \multicolumn{2}{l}{ No excluded from analysis: } & \\
\cline { 2 - 5 } Dose of sultamicillin & & $\begin{array}{l}\text { Culture } \\
\text { negative }\end{array}$ & $\begin{array}{l}\text { Not attending } \\
\text { follow up }\end{array}$ & $\begin{array}{l}\text { Culture positive. } \\
\text { Sexual intercourse } \\
\text { during follow up }\end{array}$ & $\begin{array}{l}\text { No } \\
\text { included } \\
\text { in analysis }\end{array}$ \\
\hline $1 \cdot 5 \mathrm{~g}$ (trial 1) & 168 & 7 & 14 & 8 & 139 \\
$2 \cdot 25 \mathrm{~g}$ (trial 2) & 169 & 11 & 22 & 6 & 130 \\
\hline
\end{tabular}

TABLE II Follow up visits of successfully treated patients

\begin{tabular}{|c|c|c|c|c|c|}
\hline & \multicolumn{5}{|c|}{ No of patients attending: } \\
\hline & 3 Visits & 2 Visits & $\begin{array}{l}\text { I visit } \\
>\text { I day after } \\
\text { treatment }\end{array}$ & $\begin{array}{l}1 \text { visit only } \\
\text { I day after } \\
\text { treatment }\end{array}$ & Total \\
\hline Trial 1 ( $1.5 \mathrm{~g}$ sultamicillin $)$ & 51 & 44 & 14 & 15 & 124 \\
\hline Trial $2(2 \cdot 25 \mathrm{~g}$ sultamicillin) & 50 & 41 & 16 & 15 & 122 \\
\hline
\end{tabular}

their mean age was $26 \cdot 2$ (range $15-66$ ) years, $66 \%$ (111) were born in Britain, $20 \%$ (33) in Jamaica, and $14 \%$ (24) elsewhere. In the second trial 169 patients were treated with $2.25 \mathrm{~g}$ sultamicillin and $1 \mathrm{~g}$ probenecid; their mean age was 26 (range 15-63) years, $72 \%$ (121) were born in Britain, $14 \%$ (24) in Jamaica, and $14 \%$ elsewhere. Taking the two trials together only six patients were born in Nigeria and three in Ghana. As detailed in table I, several patients in each trial were excluded because they failed to attend for follow up, because they were reinfected, or because the laboratory was unable to confirm the diagnosis with a positive culture result. Table II details the number of follow up visits made by patients accepted in each trial who responded to treatment.

Table III shows that in the first trial $124(89 \cdot 2 \%)$ of 139 patients responded to treatment. Treatment failed at $17(9 \cdot 8 \%)$ of 173 sites. The 17 documented treatment failure sites occurred in 15 patients, one woman showing positive cervical, urethral, and throat swabs at follow up. MICs were available for 14 of these organisms, of which all but two had MICs in the upper range of ampicillin and ampicillinsulbactam $(0 \cdot 25-1 \cdot 0 \mathrm{mg} / \mathrm{l})$. Of the two sensitive strains (MIC $0.03 \mathrm{mg} / \mathrm{l}$ ) one was from a man with urethritis and the other from a man with pharyngitis. Four of the organisms from patients who failed to respond were PPNG strains, two occurring in men with urethritis and the other two in women with pharyngitis.

Table IV shows that in the second trial 122 $(93.8 \%)$ of 130 patients (146 out of 154 sites) responded to treatment. The eight treatment failures concerned eight different patients.

In the first trial $62.6 \%$ and in the second $54 \%$ of available isolates had MICs of ampicillin $\leqslant 0 \cdot 12$ $\mathrm{mg} / \mathrm{l}$. There was close correlation between MICs of

TABLE III Results of trial $1(1 \cdot 5 \mathrm{~g}$ sultamicillin)

\begin{tabular}{|c|c|c|c|c|}
\hline \multirow[b]{2}{*}{ Sites of infection } & \multirow[b]{2}{*}{ No infected } & \multirow[b]{2}{*}{$\begin{array}{l}\text { No }(\%) \text { responding } \\
\text { to treatment }\end{array}$} & \multicolumn{2}{|l|}{ PPNG strains } \\
\hline & & & No infected & $\begin{array}{l}\text { No }(\%) \text { responding } \\
\text { to treatment }\end{array}$ \\
\hline \multicolumn{5}{|l|}{ Men } \\
\hline Urethritis & 91 & $81(89 \cdot 0)$ & 8 & $6(75 \cdot 0)$ \\
\hline Proctitis & 9 & $8(88 \cdot 9)$ & 0 & $(1,0)$ \\
\hline Pharyngitis & 3 & $2(66 \cdot 7)$ & 0 & \\
\hline \multicolumn{5}{|l|}{ Women: } \\
\hline Cervicitis & 35 & $34(97 \cdot 1)$ & 2 & $2(100 \cdot 0)$ \\
\hline Urethritis & 26 & $25(96 \cdot 1)$ & 2 & $2(100 \cdot 0)$ \\
\hline Proctitis & 4 & $4(100 \cdot 0)$ & 0 & \\
\hline Pharyngitis & 5 & $2(40 \cdot 0)$ & 2 & $0(0)$ \\
\hline Total sites & 173 & $156(90 \cdot 2)$ & 14 & $10(71 \cdot 4)$ \\
\hline Total patients & 139 & $124(89 \cdot 2)$ & 11 & $7(63 \cdot 6)$ \\
\hline
\end{tabular}

PPNG = Penicillinase $(\beta$ lactamase $)$ producing strains of Neisseria gonorrhoeae. 
TABLE IV Results of trial $2(2 \cdot 25 \mathrm{~g}$ sultamicillin)

\begin{tabular}{|c|c|c|c|c|}
\hline \multirow[b]{2}{*}{ Sites of infection } & \multirow[b]{2}{*}{ No infected } & \multirow[b]{2}{*}{$\begin{array}{l}\text { No }(\%) \text { responding } \\
\text { to treatment }\end{array}$} & \multicolumn{2}{|c|}{ PPNG strains } \\
\hline & & & No infected & $\begin{array}{l}\text { No }(\%) \text { responding } \\
\text { to treatment }\end{array}$ \\
\hline $\begin{array}{l}\text { Men } \\
\text { Urethritis } \\
\text { Proctitis } \\
\text { Pharyngitis }\end{array}$ & $\begin{array}{r}91 \\
11 \\
4\end{array}$ & $\begin{array}{c}88(96 \cdot 7) \\
11(100 \cdot 0) \\
1(25 \cdot 0)\end{array}$ & $\begin{array}{l}4 \\
0 \\
0\end{array}$ & $4(100 \cdot 0)$ \\
\hline $\begin{array}{l}\text { Women: } \\
\text { Cervicitis } \\
\text { Urethritis } \\
\text { Proctitis } \\
\text { Pharyngitis }\end{array}$ & $\begin{array}{r}23 \\
19 \\
3 \\
3\end{array}$ & $\begin{array}{c}23(100 \cdot 0) \\
19(100 \cdot 0) \\
3(100 \cdot 0) \\
1(33 \cdot 3)\end{array}$ & $\begin{array}{l}1 \\
1 \\
0 \\
0\end{array}$ & $\begin{array}{l}1(100 \cdot 0) \\
1(100 \cdot 0)\end{array}$ \\
\hline Total sites & 154 & $146(94 \cdot 8)$ & 6 & $6(100 \cdot 0)$ \\
\hline Total patients & 130 & $122(93 \cdot 8)$ & 5 & $5(100 \cdot 0)$ \\
\hline
\end{tabular}

PPNG $=$ Penicillinase $(\beta$ lactamase $)$ producing strains of Neisseria gonorrhoeae .

ampicillin and ampicillin-sulbactam. Table $\mathrm{V}$ shows in greater detail the in vitro sensitivities of all isolates tested.

Of the 337 patients treated in the two trials, three complained of nausea, four of nausea and abdominal pain, 13 of diarrhoea, and two developed a rash. All of these side effects were transitory and mild, and none precipitated admission to hospital. Ten patients treated with the lower dose and nine treated with the higher dose complained of these symptoms.

In addition to patients treated in these trials, 11 harbouring PPNG strains were treated with $2.25 \mathrm{~g}$ sultamicillin plus $1 \mathrm{~g}$ probenecid, of whom 10 responded satisfactorily. The total number of patients infected with these strains treated with the higher dose of sultamicillin was 16, of whom 15 responded satisfactorily.

\section{Discussion}

The emergence of total resistance to penicillin in $N$ gonorrhoeae due to $\beta$ lactamase production now poses a considerable problem over treatment. In Britain the prevalence of PPNG strains in gonococcal isolates is still only about $5 \%,{ }^{3}$ but in parts of South East Asia it is nearly $50 \% .{ }^{4}$ West Africa is the source of many of our PPNG strains. ${ }^{5}$ The prevalence in this series was lower than previously reported.

In Britain oral ampicillin is probably the antimicrobial most commonly used in treating gonorrhoea, ${ }^{6}$ although dosage varies. In the United States the recommended dose for uncomplicated gonorrhoea is ampicillin $3.5 \mathrm{~g}$ plus probenecid $1 \mathrm{~g}$ by mouth. ${ }^{7}$ This treatment is ineffective against PPNG strains and would be poor first line treatment in South East Asia. For PPNG strains usual treatments are either spectinomycin, resistance to which has been reported, ${ }^{8}$ or a new cephalosporin such as cefotaxime. ${ }^{5}$ Such medications are expensive and, as most of them must be given intramuscularly, syringes and needles further increase the cost. Injections also take more time for nurses to administer and are less well tolerated by patients.

Clearly a single dose oral treatment for gonorrhoea that would cover all strains would be more acceptable. Sultamicillin with probenecid may provide such an alternative. The findings with the $1.5 \mathrm{~g}$ regimen were unsatisfactory. The results with the $2 \cdot 25 \mathrm{~g}$ dosage resembled those with sultamicillin $2 \mathrm{~g}$ plus probenecid $1 \mathrm{~g}$ reported by Atia et al, ${ }^{9}$ and show sultamicillin to be well tolerated and effective against PPNG and non-PPNG strains. Among

TABLE V In vitro sensitivity of 558 strains of gonococci isolated during two trials in 1982 and 1983

\begin{tabular}{|c|c|c|c|c|c|c|c|c|c|c|c|}
\hline \multirow[b]{2}{*}{ Antibiotic } & \multirow{2}{*}{$\begin{array}{l}\text { Type of } \\
\text { strain }\end{array}$} & \multirow{2}{*}{$\begin{array}{l}\text { No of } \\
\text { isolates }\end{array}$} & \multicolumn{9}{|c|}{$\%$ isolates inhibited by MICs (mg/l) of: } \\
\hline & & & $\leqslant 0.01$ & 0.03 & 0.06 & $0 \cdot 12$ & 0.25 & $0 \cdot 5$ & 1 & 2 & $\geqslant 4$ \\
\hline Ampicillin & $\begin{array}{l}\text { Non-PPNG } \\
\text { PPNG }\end{array}$ & $\begin{array}{r}528 \\
30\end{array}$ & 3 & 23 & $12 \cdot 5$ & 14 & 36 & $10 \cdot 5$ & 1 & $(0 \cdot 2)$ & 100 \\
\hline Sulbactam & $\begin{array}{l}\text { Non-PPNG } \\
\text { PPNG }\end{array}$ & $\begin{array}{r}528 \\
30\end{array}$ & & & $(0.4)$ & 10 & 23 & 9 & $\begin{array}{l}14 \cdot 5 \\
20\end{array}$ & $\begin{array}{l}27 \cdot 5 \\
63\end{array}$ & $\begin{array}{l}16 \\
17\end{array}$ \\
\hline $\begin{array}{l}\text { Sulbactam and } \\
\text { ampicillin }(1: 1)\end{array}$ & $\begin{array}{l}\text { Non-PPNG } \\
\text { PPNG }\end{array}$ & $\begin{array}{r}528 \\
30\end{array}$ & 5 & $27 \cdot 5$ & 6 & 20 & $\begin{array}{l}33 \\
10\end{array}$ & $70^{7 \cdot 5}$ & $\begin{array}{r}1 \\
20\end{array}$ & & \\
\hline
\end{tabular}

PPNG $=$ Penicillinase $(\beta$ lactamase $)$ producing strains of Neisseria gonorrhoeae .

Figures in parentheses represent $<1 \%$ of isolates. 
patients with anogenital gonorrhoea the response in the first trial was $128(92 \cdot 1 \%)$ out of 139 and in the second $127(97 \cdot 7 \%)$ out of 130 . A $95 \%$ response is generally regarded as acceptable in Britain for first line treatment for anogenital gonorrhoea, but lower cure rates are unsatisfactory for uncomplicated infection. As treatment with single dose ampicillin gives poor results in gonococcal pharyngitis, a course of antimicrobial treatment is apparently necessary to cure this condition.

\section{References}

1. Phillips I, Humphrey D, Middleton A, Nicol C. Diagnosis of gonorrhoea by culture on a selective medium containing vancomycin, colistin, nystatin and trimethoprim (VCNT). British Journal of Venereal Diseases 1972; 48:287-92.

2. Phillips I. $\beta$-lactamase-producing penicillin-resistant gonococci. Lancet 1976; ii:656-7.
3. Communicable Disease Surveillance Centre. Penicillinaseproducing Neisseria gonorrhoeae in Britain 1982. Br Med J 1983; 286: 1628-9.

4. Panikabutra K, Ariyarit C, Chitwarakorn C, Saensanoh C. Cefaclor and cefamandole as alternatives to spectinomycin in the treatment of men with uncomplicated gonorrhoea. British Journal of Venereal Diseases 1983;59:298-301.

5. Thin RN, Barlow D, Eykyn S, Phillips I. Imported penicillinase producing Neisseria gonorrhoeae becomes endemic in London. British Journal of Venereal Diseases 1983;59:364-8.

6. Adler MW. Diagnostic treatment and reporting criteria for gonorrhoea in sexually transmitted diseases clinics in England and Wales. 2: Treatment and reporting criteria. British Journal of Venereal Diseases 1978;54:15-23.

7. Centers for Disease Control. Sexually transmitted diseases treatment guidelines. MMWR 1982;31:532-60.

8. Easmon CSF, Ison CA, Bellinger CM, Harris JRW. Emergence of resistance after spectinomycin treatment for gonorrhoea due to $\beta$-lactamase-producing strains of Neisseria gonorrhoeae. Br Med J 1982; 284:1604-5.

9. Atia WA, Emmerson AM, Holmes D. Sultamicillin in the treatment of gonorrhoea caused by penicillin sensitive and penicillinase producing strains of Neisseria gonorrhoeae. British Journal of Venereal Diseases 1983;59:293-7. 